\title{
System prawa dotacyjnego oraz prawo o dotacjach udzielanych z budżetów samorządów
}

\section{Dotacja jako wydatek publiczny}

Jednym $\mathrm{z}$ podstawowych tematów, którymi zajmuje się nauka finansów publicznych jest instytucja dotacji. Dotacja, jako przedmiot przepisów prawnych, znajduje odzwierciedlenie w prawie finansów publicznych, którego podstawowym składnikiem jest obecnie ustawa z 27 sierpnia 2009 r. o finansach publicznych (Dz.U. Nr 157, poz. 1240 ze zm. - dalej: ufp).

Słowo „dotacja” wywodzi się z łaciny średniowiecznej, w której dotatio oznaczało „wyposażenie” kogoś w dobra materialne. W językach współczesnych pojęcie: „dotacja” stosowane jest zamiennie z pojęciem: „subwencja”. Tak pierwsze, jak i drugie słowo w języku potocznym służy do określenia szczególnych przypadków zaopatrzenia kogoś lub dostarczenia komuś środków pieniężnych stanowiących środki publiczne pochodzące $\mathrm{z}$ budżetu lub funduszu celowego. Według definicji słownikowych, dotacja to „dar, darowizna, zapis ustanowiony przez donatora, fundatora na rzecz donatariusza"'. Z kolei słowo subwencja stosowane jest dla określenia „pomocy finansowej udzielanej przez państwo przedsiębiorcom, instytucjom, osobom fizycznym”. W języku potocznym pojęcie „dotacja” ma charakter pojęcia podstawowego, zaś „,subwencja” okazuje się być szczególnym rodzajem takiej dotacji w jej znaczeniu ogólnym. W języku potocznym dotacja pochłania zatem pojęcie subwencja ${ }^{3}$.

1 W. Kopaliński, Stownik wyrazów obcych i zwrotów obcojęzycznych, wydanie internetowe: http://www.slownik-online.pl/index.php (dostęp 1.06.2015 r.).

2 Ibidem.

3 Według E. Malinowskiej-Misiąg i W. Misiąga (Finanse publiczne w Polsce, Warszawa 2007, s. 152-153); terminologiczne rozróżnianie dotacji i subwencji jest zabiegiem sztucznym, gdyż niektóre dotacje wbrew ich znaczeniu mają niekiedy charakter ogólny; 
Pochodzenie dotacji i subwencji z budżetu lub funduszu celowego przesądza o tym, że ich udzielanie ma źródło w przepisach prawa finansowego. Nauka finansów uznaje je za tzw. wydatki transferowe. W nauce finansów publicznych rozróżnia się:

- wydatki realne (rzeczywiste, nabywcze lub inaczej: wydatki bezpośrednie);

- wydatki transferowe (przelewowe) ${ }^{4}$.

Wydatki realne (wydatki bezpośrednie, wydatki nabywcze) to wynikające z norm prawa prywatnego zakupy dóbr i usług, wypłacanie płac i pochodnych od wynagrodzeń oraz dokonywane wydatki inwestycyjne (zakupy lub sfinansowanie zamówionej inwestycyji) na potrzeby jednostek sektora finansów publicznych. Cechuje je w większości ekwiwalentność dokonywanej zapłaty w zamian za świadczenie otrzymywane przez jednostkę publiczną. Wydatkami takimi nie są transfery finansowe, które stanowią wyraz świadczenia jednostronnego (niewzajemnego) i z zasady nieekwiwalentnego (brak równowartości). Transfery zewnętrzne stanowią wyraz zasilania podmiotów prywatnych ze środków publicznych i mogą być związane $z$ realizowaniem przez władze publiczne ważnych celów społecznych lub gospodarczych ${ }^{5}$. Dotacje i subwencje nie są jedynym rodzajem wydatków transferowych. Należą do nich również wypłacane $\mathrm{z}$ budżetu nagrody, zapomogi, stypendia $\mathrm{i}$ inne wydatki oparte na normach prawa publicznego.

W przepisie art. 126 ufp zawarto prawną definicję dotacji. W dalszych przepisach ustawy wyrażono definicje oddające istotę dotacji celowych (art. 127 ufp), dotacji przedmiotowych (art. 130 ufp) i dotacji podmiotowych (art. $131 \mathrm{i}$ art. $218 \mathrm{ufp}$ ). W ustawie o finansach publicznych, ani w żadnej innej ustawie prawa finansowego nie zawarto natomiast definicji ogólnej dla wydatków transferowych, ani definicji dla innych niż dotacje rodzajów takich wydatków ${ }^{6}$.

podobnie por. A. Borodo: Samorząd terytorialny. System prawnofinansowy, Warszawa 1997, s. 117-119. Pogląd zbliżony reprezentują również E. Chojna-Duch: Struktura dotacji budżetowej. Studium teoretycznoprawne, Warszawa 1988, s. 29 oraz T. Dębowska-Romanowska; Zagadnienia prawne wydatków na rzecz osób trzecich; Łódź 1993 r., s. 44 i n.

4 S. Owsiak, Finanse Publiczne. Teoria i praktyka, Warszawa 1997, s. 176 i n.

5 Ibidem, s. 177.

$6 \mathrm{~W}$ pierwotnie opracowanym projekcie obecnej ustawy o finansach publicznych (autorstwa Z. Gilowskiej, W. Mistąga, T. Mierzwy) z przełomu lat 2006/2007 zamieszczono we wstępie definicje dotacji, a w dalszych częściach samodzielny dział grupujący przepisy dotyczące poszczególnych rodzajów wydatków transferowych budżetu, w tym dotacji. Niestety w dalszych pracach w Ministerstwie Finansów, rezygnując z celowości zamieszczania ww. działu ogólnego, niektóre przepisy (bez zatroszczenia się o literę prawa) wydzielono z tekstu i zamieszczono w dziale ustawy dotyczącym budżetu państwa. Jedynie przepisy o windykacji zwrotu dotacji przeredagowano i zamieszczono oddzielnie dla dotacji z budżetu państwa i oddzielnie dla dotacji z budżetu samorządu. 
Zgodnie $\mathrm{z}$ definicją normatywną $\mathrm{z}$ art. 126 ufp, podstawą prawną udzielenia dotacji z budżetu państwa lub budżetu jednostki samorządu terytorialnego musi być zawsze przepis prawa publicznego zawarty w ustawie bądź w umowie międzynarodowej. W przypadku braku tego rodzaju podstaw nie jest możliwe, aby w miejsce dotacji organ - jako reprezentant osoby prawnej (Skarbu Państwa lub samorządu terytorialnego) - udzielał darowizny ogólnej lub darowizny z poleceniem na podstawie art. 888 i nast. ustawy z dnia 23 kwietnia 1964 r. Kodeks cywilny (Dz.U. z 2014 r., poz. 121 ze zm.). Właśnie fakt zamieszczenia w prawie publicznym przepisów o wydatkach transferowych (w tym o dotacjach) jest dowodem na brak podstaw do udzielania ze środków publicznych darowizny pieniężnej.

Druga i nie mniej kluczowa cecha dotacji, jako jej „szczególne rozliczenie", to dostarczenie przez beneficjenta dowodów jej wykorzystania - zgodnego z jej przeznaczeniem - oraz dokonanie przez jednostkę obsługującą organ szczególnych czynności w zakresie jej rozliczenia. Cechy powyższe, a także właściwa dla zwrotu dotacji egzekucja administracyjna, wraz ze szczególną odpowiedzialnością prawną organu i beneficjenta, uzasadniają wniosek, że poza przypadkami wynikającymi z przepisów prawa publicznego organ administracji rządowej lub jednostka samorządu terytorialnego (dalej: JST) nie może bez oparcia na wyraźnych przepisach prawa określonemu wydatkowi budżetowemu nadawać formy dotacji.

\section{Struktura prawa dotacyjnego}

Przepisy prawne dotyczące dotacji stanowią specyficzny element prawa regulującego wydatki publiczne. Dla celów porządkowych zasadne jest nazywać je „prawem dotacyjnym” (czy np. „prawem o dotacjach”). Takie określenie ułatwia porządkowanie i strukturyzację ogółu przepisów dotacyjnych, jak również może być pomocne na etapie stosowania prawa i tworzenia prawa traktującego o dotacjach.

$\mathrm{Z}$ punktu widzenia funkcji, jaką pełnią poszczególne przepisy prawa dotyczącego dotacji, należałoby przyjąć, że na prawo dotacyjne w zakresie dotacji udzielanych z budżetu państwa i z budżetu JST składają się trzy grupy norm:

- część ogólna prawa dotacyjnego,

- tytuły dotacyjne,

- przepisy wspólne. 
Przepisy ogólne zawierają definicję dotacji jako takiej oraz definicje trzech rodzajów dotacji (dotacji celowej, dotacji przedmiotowej i dotacji podmiotowej). Drugim elementem przepisów prawa dotacyjnego są przepisy szczególne ustaw lub, co zakłada ustawa, przepisy umów międzynarodowych, które zawierają właściwe „tytuły dotacyjne”. Pod pojęciem "tytuł dotacyjny” proponuję rozumieć nie tyle podstawę prawną do posłużenia się określoną dotacją, ile również przepisy określające jej wysokość, sposób i tryb udzielenia, jej przeznaczenie oraz sposób i tryb rozliczania.

Część trzecia to przepisy wspólne, znajdujące zastosowanie lub mogące znaleźć zastosowanie w odniesieniu do każdej dotacji, której udzielono na podstawie przepisu - tytułu dotacyjnego. Przepisy te obejmują między innymi:

- regulacje z art. 53 i 54 ufp, które znajdą zastosowanie na poziomie organu (tj. donatora, dysponenta) w fazie uruchamiania wydatków na dotację i w fazie rozliczania dotacji;

- właściwe do klasyfikowania wydatków dotacyjnych podziałki z rozporządzenia Ministra Finansów z dnia 2 marca 2010 r. w sprawie szczegółowej klasyfikacji dochodów, wydatków, przychodów i rozchodów oraz środków pochodzących ze źródeł zagranicznych (Dz.U. z 2014 r., poz. 1053 ze zm.),

- właściwe dla ewidencjonowania operacji zaciągnięcia zobowiązania, wypłaty dotacji i zaksięgowania rozliczenia - przepisy rozporządzenia Ministra Finansów z dnia 5 lipca 2010 r. w sprawie szczególnych zasad rachunkowości oraz planów kont dla budżetu państwa, budżetów jednostek samorządu terytorialnego, jednostek budżetowych, samorządowych zakładów budżetowych, państwowych funduszy celowych oraz państwowych jednostek budżetowych mających siedzibę poza granicami Rzeczypospolitej Polskiej (Dz.U. z 2013 r., poz. 289),

- przepisy dotyczące obowiązku zwrotu dotacji i dochodzenia jego wykonania (windykacji) przez organ z art. 168 i 169 oraz art. 251 i 252 ufp,

- przepis art. $64 \mathrm{w}$ zw. z art. 60 pkt 1 ufp dotyczący zasad udzielania ulg $\mathrm{w}$ spłacie należności budżetu $\mathrm{z}$ tytułu zwrotu dotacji, wraz $\mathrm{z}$ dodatkowo stosowanymi przepisami prawa pomocy publicznej wówczas, gdy udzielanie ulgi jest pomocą publiczną w rozumieniu art. 107 ust. 1 Traktatu o Funkcjonowaniu Unii Europejskiej (t.j.: Dz.Urz. UE C Nr 115 z 9.5.2008 r.),

- związane z sankcjami z tytułu naruszenia niektórych norm prawa dotacyjnego - przepisy art. 8 i 9 ustawy z dnia 17 grudnia 2004 r. o odpowiedzialności za naruszenie dyscypliny finansów publicznych (Dz.U. z 2013 r., poz. 168) oraz art. 82 ustawy z dnia 10 wrze- 
śnia 1999 r. Kodeks karny skarbowy (Dz.U. z 2013 r., poz. 186 ze zm.),

- przewidujące umowę o udzielenie dotacji celowej uzupełniającą niekompletne przepisy tytułu dotacyjnego - przepisy art. 150 i art. 250 ufp,

- odnoszący się do dotacji celowej udzielonej z budżetu państwa obowiązek prowadzenia przez jej beneficjenta odrębnej ewidencji księgowej środków z dotacji celowej (art. 152 ust. 1 ufp).

Omówienie zarysowanej powyżej struktury prawa dotacyjnego, ze względów porządkowych, najdogodniej jest rozpocząć od omówienia tytułów dotacyjnych.

\section{Tytuły dotacyjne}

Najliczniejszą grupą unormowań prawa dotacyjnego są właściwe tytuły dotacyjne. Chodzi tutaj nie tylko o przepis wyrażający podstawę prawną do udzielania określonej dotacji, ale również niejako o „resztę" regulacji kształtującej tę dotację, oczywiście z wyłączeniem ww. przepisów wspólnych wszystkim dotacjom. Przepisy te zawarte są w ustawach szczególnych prawa administracyjnego oraz w niektórych przepisach ufp (np. podstawa prawna umożliwiająca udzielanie dotacji celowej-inwestycyjnej dla samorządowego zakładu budżetowego $\mathrm{z}$ art. 15 ust. 3 pkt 3 ufp). Niektóre z przepisów ustawowych zawierają delegacje do wydania rozporządzeń wykonawczych, w tym niekiedy aktów prawa miejscowego. Normy z aktów wykonawczych wraz z właściwą dla dotacji ustawą również składają się na tytuły dotacyjne. Przykładem są dotacje z budżetu JST na wspieranie rewaloryzacji zabytków wpisanych do rejestru zabytków udzielane na podstawie art. 81 ustawy z dnia 23 lipca 2003 r. o ochronie zabytków i opiece nad zabytkami (Dz.U. z 2014 r., poz. 1446 ze zm.) oraz uchwały prawa miejscowego określającej zasady i tryb ich udzielania.

Przepisy ustaw i aktów wykonawczych (z jednoczesnym posiłkowaniem się definicją dotacji $\mathrm{z}$ art. 126, 127, 130 i 131 ufp) umożliwiają ustalenie beneficjenta, ustalenie przeznaczenia dotacji, wysokości oraz zasad i trybu udzielania i rozliczania dotacji.

Warte odnotowania jest to, że w art. 150 i art. 250 ufp zamieszczono przepisy wspólne dotacjom celowym, jakie pełnią rolę pomocniczą, na wypadek gdyby w przepisie - tytule dotacyjnym nie zawarto regulacji kompletnych. Wówczas kwestie przeznaczenia dotacji celowej, terminu 
jej przekazania oraz sposobu i terminu rozliczenia określa organ w umowie zawieranej z beneficjentem dotacji celowej ${ }^{7}$.

Wśród tytułów dotacyjnych zawartych bezpośrednio w ustawie o finansach publicznych istotną rolę pełni zapis art. 221. W praktyce przepis budzi szereg kłopotów interpretacyjnych. Generalnie ustawodawca reguluje pewną konstrukcję ogólną, model udzielania dotacji celowej na sfinansowanie zadania JST, które samorząd zleca podmiotowi spoza sektora finansów publicznych i niedziałającemu w celu osiągania zysku. Przepis art. 221 w ust. 1 ufp formułuje tutaj podstawę dotacji, która służy finansowaniu realizacji ustawowych zadań samorządu - przekazanych podmiotowi trzeciemu (spoza administracji). Zadania samorządu określa ustawodawstwo szczególne. Co wymaga jednak podkreślenia, w przepisie art. 221 ufp nie idzie o zlecenie ustawowych zadań samorządu tak, aby beneficjent stawał się elementem administracji publicznej. Konstrukcja zlecenia zadania sprowadza się w istocie do powierzenia realizacji projektu (działania lub przedsięwzięcia celu publicznego), którego realizacja przez beneficjenta doprowadzi po stronie samorządu do wykonania ciążących na nim zadań ustawowych (np. z zakresu upowszechniania kultury narodowej). Po zarysowaniu ogólnej konstrukcji zlecania zadań JST w zapisie art. 221 ust. 2 ufp dochodzi do odesłania do właściwego tytułu dotacyjnego, jaki mieści się dopiero w przepisach art. 11-19a ustawy z dnia 24 kwietnia 2003 r. o działalności pożytku publicznego i o wolontariacie (Dz.U. Nr 96, poz. 873 ze zm. - dalej: udppiw). W przepisie art. 4 ust. 1 udppiw określono katalog celów publicznych, w zakresie których administracja ich realizację może zlecać i finansować dotacją celową. Poza powyższym odesłaniem z ust. 1 art. 221 ufp, w dalszej części przepis art. 221 ufp zawiera samodzielny już tytuł dotacyjny, umożliwiający samorządowi zlecanie tych jego zadań, które nie są objęte katalogiem z art. 4 udppiw (np. zadania z zakresu promocji danego samorządu). Zleca się je i dotuje z zastosowaniem art. 221 ust. 2 ufp i z uwzględnieniem przepisów $\mathrm{z}$ uchwały prawa miejscowego $\mathrm{z}$ art. 221 ust. 4 . W przepisie art. 221 ust. 3 zamieszczono regulację wspólną dla tytułu dotacyjnego udppiw i tytułu z art. 221 ust. 2 ufp, którą ustawodawca określił podstawowe składniki (essentialie) umowy o dotację na zadanie zlecone.

7 Przykładem zastosowania art. 250 ufp jest zawieranie tego rodzaju umowy o dotację celową między JST, jako organizatorem a macierzystą instytucją kultury. Przepis art. 28 ust. 3 pkt 2 i 3 ustawy z dnia 25 października 1991 r. o organizowaniu i prowadzeniu działalności kulturalnej (Dz.U. z 2012 r., poz. 406 ze zm.) przewiduje, że organizator może udzielić instytucji kultury dotacji celowej na inwestycję oraz dotacji celowej na realizację określonych zadań. Dzięki przepisowi art. 150 i art. 250 ufp możliwe jest uruchamianie tego rodzaju dotacji celowych dla państwowej instytucji kultury i samorządowej instytucji kultury, gdyż zawierana umowa organu z beneficjentem uzupełnia regulację z ww. ustawy o niezbędne elementy dla powstania stosunku prawno-finansowego. 
Opisane powyżej przykłady tytułów dotacyjnych nie obejmuje wszystkich tytułów funkcjonujących w obecnie obowiązującym prawie. Podkreślenia jednak wymaga to, że liczba podstaw prawnych do udzielania dotacji stanowi zawsze zbiór zamknięty, który ustawodawca poszerza o nowe tytuły lub pomniejsza. Przedstawiane (przykładowo) tytuły dotacyjne nie obejmują zatem całości.

\section{Definicje dotacji}

W art. 126 ufp wyrażono prawną definicję dotacji, jako wydatku publicznego. $Z$ kolei $w$ art. 127, art. 130, art. 131 zawarto definicję i zarazem rozróżnienie dotacji na trzy ich rodzaje: dotacje celowe, dotacje przedmiotowe, dotacje podmiotowe. Polskie prawo zna zatem tylko trzy odrębne od siebie rodzaje dotacji ${ }^{8}$. Odmiennie od tego podziału nauka finansów rozróżnia dotacje w oparciu o kryteria dychotomiczne wydzielając w ten sposób m. in: dotacje ogólne i odrębne od nich dotacje celowe oraz dotacje przedmiotowe i odrębne dotacje podmiotowe. Pojęcia nauki i pojęcia $z$ ustawy o finansach publicznych mają odmienne od siebie znaczenia. Znaczenie każdej z trzech rodzajów dotacji z ustawy o finansach publicznych w najmniejszym stopniu nie pokrywają się z tak samo brzmiącymi pojęciami, które nauka finansów publicznych stosuje dla podziałów i charakterystyki dotacji występujących w systemach prawnych współczesnych państw.

\subsection{Ogólna definicja dotacji}

\section{Podstawa prawna udzielania dotacji}

W aktualnym stanie prawnym ogólną definicję dotacji zawiera art. 126 ufp, według którego „Dotacje są to podlegające szczególnym zasadom rozliczania środki z budżetu państwa, budżetu jednostek samorządu terytorialnego oraz z państwowych funduszy celowych przeznaczone na

$8 \mathrm{Z}$ orzecznictwie ostatnich lat zdarzało się niejednokrotnie, że sądy administracyjne nazywały dotacje z art. 80 i art. 90 ustawy o systemie oświaty, dotacjami podmiotowo-celowymi. Praktyce takiej przeciwstawił się Naczelny Sąd Administracyjny w wyroku z dnia 12 grudnia 2013 r. (II GSK 1482/12) przypominając, że polskie prawo rozróżnia tylko trzy odmienne od siebie rodzaje dotacji. Zdaniem NSA ww. dotacje z ustawy o systemie oświaty noszą w pełni cechy dotacji podmiotowej z art. 131 ufp i w najmniejszym stopniu nie wypełniają cech dotacji celowej. 
podstawie niniejszej ustawy, odrębnych ustaw lub umów międzynarodowych, na finansowanie lub dofinansowanie realizacji zadań publicznych".

W świetle art. 126 ufp, podstawą prawną udzielenia dotacji z budżetu lub funduszu celowego może być wyłącznie przepis ustawowy albo przepis umowy międzynarodowej. Przepisem ustawowym, jako podstawą dotacji, może być przepis „ustawy odrębnej” (w rozumieniu art. 2 pkt 4 ufp) bądź przepis szczególny ufp.

Dopuszczona w art. 126 ufp możliwość wyprowadzania tytułów dotacyjnych za pomocą umów międzynarodowych (w tym za pomocą przepisów prawa Unii Europejskiej) wynika z normy konstytucyjnej określającej źródła prawa (art. 87 ust. 1 i art. 90 Konstytucji RP). Co jednak wymaga podkreślenia, pod aktualnym stanem prawnym Rzeczpospolita Polska nie jest sygnatariuszem takich umów międzynarodowych, które wyrażałyby bezpośrednio tytuł prawny umożliwiający posłużenie się dotacją ze środków budżetu państwa lub budżetu JST. Należy przy tym odnotować, że akty normatywne Unii Europejskiej stosuje się do takich dotacji, które udzielane na podstawie prawa krajowego stanowią zarazem „pomoc publiczną" w rozumieniu art. 107 ust. 1 Traktatu o funkcjonowaniu Unii Europejskiej. Jednak w takich przypadkach prawo UE nie stanowi bezpośredniej podstawy do udzielania dotacji dla przedsiębiorcy, ale działając równolegle z prawem polskim ogranicza przeznaczenie pomocy publicznej otrzymanej przez beneficjenta oraz wprowadza dodatkowe regulacje związane z trybem udzielania pomocy.

\section{Przeznaczenie jako kluczowa cecha dotacji}

Aktualna definicja dotacji $\mathrm{z}$ art. 126 ufp uwypukla powiązanie dotacji ze wspólnym wszystkim trzem rodzajom dotacji ich „przeznaczeniem” i „rozliczaniem”. Dotacje według art. 126 ufp są przeznaczone na finansowanie lub dofinansowanie realizacji zadania publicznego. Właściwe dotacjom „przeznaczenie” odróżnia dotacje od subwencji, nazywanych niekiedy w doktrynie dotacjami ogólnymi. Właśnie ze względu na „przeznaczenie dotacji” prawo wyróżnia trzy rodzaje dotacji. Dlatego, co do zasady, każda dotacja konstruowana przez ustawodawcę i uzupełniana aktami wykonawczymi do ustawy musi mieć jednoznacznie do-

9 Por. T. Dębowska-Romanowska, Zagadnienia prawne wydatków publicznych na rzecz osób trzecich, Łódź 1993 r., s. 43 i n. Subwencja jest otrzymywanym od państwa dochodem ogólnym, z którym prawo nie wiąże żadnego konkretnego przeznaczenia. Należy jednak zaznaczyć, że polski ustawodawca nie zawsze konsekwentnie stosuje pojęcia „dotacja” $i$,subwencja”. Na przykład: wydatek transferowy z budżetu państwa z art. 50a ustawy z dnia 13 listopada 2003 r. o dochodach jednostek samorządu terytorialnego (Dz.U. z 2015 r., poz. 513 ze zm.), który rekompensuje samorządowi utracone dochody, jest nazywany dotacją, pomimo że prawo nie wiąże z nim jakiegokolwiek „przeznaczenia” immanentnego dla każdego z trzech rodzajów dotacji. 
określone jej przeznaczenie wraz z miarodajnym dla tego przeznaczenia wskazaniem danych finansowych, którymi beneficjent rozlicza się $\mathrm{z}$ wykorzystania dotacji - zgodnego z jej przeznaczeniem ${ }^{10}$. Wyrazem domknięcia ogólnej konstrukcji dotacji są wspólne dotacjom przepisy art. 168 i art. 169 ufp oraz art. 251 i art. 252 ufp, które zakładają zwrot dotacji niewykorzystanej oraz zwrot dotacji wykorzystanej niezgodnie z jej przeznaczeniem.

\subsection{Dotacje celowe}

Definicję dotacji celowych udzielanych z budżetu państwa zawiera art. 127 ufp. Posiłkowo definicję dotacji celowych $\mathrm{z}$ budżetu państwa praktyka stosuje dla wykładni prawa dotyczącego dotacji celowych udzielanych z budżetu JST. Ich istotą jest przekazanie beneficjentowi środków pieniężnych przeznaczonych na sfinansowanie (lub dofinansowanie) konkretnego zadania (celu lub przedsięwzięcia), w wyniku czego beneficjent poniesie wydatki, o których wysokości i strukturze rodzajowej decyduje zazwyczaj organ udzielający dotacji. Przykładem są powołane wcześniej dotacje z ustawy o działalności pożytku publicznego i o wolontariacie, dotacje $\mathrm{z}$ budżetu państwa dla JST na zadania zlecone samorządom, dotacje $\mathrm{z}$ art. 73-78 i art. 81 ustawy o ochronie zabytków i opiece nad zabytkami.

W zasadzie przeważająca część zawartych $\mathrm{w}$ aktualnym prawie tytułów dotacyjnych polski ustawodawca formułuje w postaci właściwej dla dotacji celowych. Najczęściej dotacje celowe w ostatnich latach przyjmują formę dotacji udzielanych fakultatywnie, bądź dotacji wymagających zaangażowania od beneficjenta jego środków własnych. Ma to uzasadnienie w powolnym odstępowaniu od posługiwania się dotacjami podmiotowymi (czyli dotacjami na dofinansowanie jakichkolwiek wydatków

10 Przykładem braków w ustawowej konstrukcji dotacji są dotacje dla szkół prowadzących kwalifikacyjne kursy zawodowe z art. 80 ust. 8-9 i art. 90 ust. 8-9 ustawy z dnia 7 września 1991 r. o systemie oświaty (Dz.U. z 2014 r. Nr 256, poz. 2572 ze zm.). Typowe dotacje oświatowe (podmiotowe) z ustępów art. 80 i art. 90 poprzedzających te przepisy mają jednoznacznie uregulowane przeznaczenie (ust. 3d art. 80 i art. 90) wraz z odestaniem do prawa miejscowego regulującego rodzaj danych, jakimi beneficjent rozlicza się z wykorzystania dotacji oświatowych (ust. 4 art. 80 i art. 90). Tymczasem dla ww. dotacji na kwalifikacyjne kursy zawodowe nie określono ich przeznaczenia i zasad rozliczania wydatkami związanymi z ich przeznaczeniem. Czyni to je de facto dotacjami ogólnymi w rozumieniu nauki finansów publicznych. Braki pod znakiem zapytania stawiają zaliczanie ww. dotacji do dotacji jako takich w rozumieniu art. 126 ufp. Dotacje te nie spełniają również cech z definicji dotacji celowej (art. 127 ufp), dotacji przedmiotowej (art. 130 ufp) i dotacji podmiotowej (art. 131 ufp). 
statutowych beneficjenta), a zarazem w niechęci prawodawcy do ustalania obiektywnych kosztów świadczenia usług publicznych dofinansowywanych dotacją przedmiotową.

\subsection{Dotacje przedmiotowe}

W definicji legalnej dotacji przedmiotowej (inaczej: produktowej) w art. 130 ust. 1 i art. 219 ufp uwypukla się jej przeznaczenie na kompensatę kosztów świadczenia ustawowo określonej usługi publicznej lub kosztów wytwarzania określonych w ustawie wyrobów. Analiza szczegółowych tytułów prawnych skłania do wniosku, że dotacja przedmiotowa z woli ustawodawcy może być udzielona wówczas, gdy wpływy z usługi nie pokrywają pełnych kosztów jej wytworzenia lub gdy usługę publiczną podmiot świadczy nieodpłatnie. W ślad za tym idzie dopłata do kosztów jednostkowych usługi.

Przykładem jest dopłata dla samorządowego zakładu budżetowego $\mathrm{z}$ tytułu różnicy między ceną korzystania $\mathrm{z}$ basenu gminnego a pełnymi kosztami usługi z art. 14 pkt 7 i art. 15 ust. 3 pkt 1 w zw. z art. 219 ufp. Inny przykład to dotacja przedmiotowa udzielana z budżetu państwa w sytuacjach zwolnień lub ulg w opłatach za usługi pocztowe dla operatora świadczącego usługi pocztowe $\mathrm{z}$ art. 27 ustawy z dnia 23 listopada 2012 r. Prawo pocztowe (Dz.U. z 2012 r., poz. 1529).

\subsection{Dotacje podmiotowe}

Trzecim rodzajem dotacji, zamykającym ich katalog, są dotacje podmiotowe definiowane w art. 131 ufp. Przepisy ufp nie zawierają tytułów umożliwiających udzielanie dotacji podmiotowych, ale zwierają je przepisy odrębne. Według art. 131 ufp dotacja podmiotowa stanowi środki dla podmiotu wskazanego w odrębnej ustawie lub w umowie międzynarodowej, przeznaczone wyłącznie na dofinansowanie jego działalności bieżącej określonej w odrębnej ustawie lub w umowie międzynarodowej. Zaznaczyć przy tym należy, że przepis art. 218 ufp w zakresie udzielanych $z$ budżetu JST dotacji podmiotowych przewiduje, iż udzielanie dotacji podmiotowej w samorządach nie może wynikać z przepisu prawa międzynarodowego. Przykładem dotacji podmiotowych są dotacje dla prowadzonych przez osoby fizyczne lub osoby prawne szkół, przedszkoli, placówek oświatowych z art. 80 i 90 ustawy z dnia 7 września 1991 r. o systemie oświaty (Dz.U. z 2014 r. Nr 256, poz. 2572 ze zm.), dotacje dla spółek wodnych udzielane z budżetu państwa na podstawie art. 164 ust. 5 ustawy z dnia 18 lipca 2001 r. Prawo wodne (Dz.U. z 2015 r., poz. 469) 
oraz dotacje dla instytucji zrzeszających mniejszości narodowe $\mathrm{z}$ art. 18 ustawy z dnia 6 stycznia 2005 r. o mniejszościach narodowych i etnicznych oraz o języku regionalnym (Dz.U. z 2015 r., poz. 573).

Wyjątkowy charakter dotacji podmiotowej wynika $\mathrm{z}$ faktu, że typowe dla niej „ogólne przeznaczenie” i krąg jej beneficjentów określa ustawa lub prawo międzynarodowe. Innymi słowy, każdorazowo w przepisie konkretnego tytułu dotacyjnego uściślona jest dotowana „działalność bieżąca" beneficjenta i tylko wydatkami z nią związanymi beneficjent będzie mógł rozliczając wykorzystanie dotacji podmiotowej. W konsekwencji rozliczenie dotacji podmiotowej to uprawdopodobnienie, że beneficjent wykorzystał ją na dofinansowanie do swojej działalności bieżącej, czego dowodem są konkretnie poniesione na nią wydatki. Co również wymaga podkreślenia, dotacja podmiotowa niewykorzystana, jak każda dotacja, podlega zwrotowi do budżetu na zasadach $\mathrm{z}$ art. $168 \mathrm{i}$ art. $251 \mathrm{ufp}$.

Beneficjentowi korzystającemu $\mathrm{z}$ dotacji podmiotowej problemów nastręcza lapidarność określenia $\mathrm{z}$ art. 131 ufp, gdzie mowa o jej przeznaczeniu „na działalność bieżącą". Pojęcie „działalność bieżąca” nie zostało wprost zdefiniowane w ustawie o finansach publicznych. Ze względu na brak wyraźnego wyjaśnienia, pojęcie „działalność bieżąca” nie jest tożsame ze stosowanym w ustawie pojęciem „wydatki bieżące”, które obejmują określoną kategorię wydatków jednostek budżetowych (innych niż wydatki majątkowe). Oczywiście, w planowaniu budżetowym dotacja podmiotowa udzielana beneficjentowi z budżetu państwa lub budżetu JST zawsze jest wydatkiem bieżącym. Powyższe stawia wymagania wobec ustawodawcy, aby ustanawiając tytułu dotacyjny w przypadku dotacji podmiotowych precyzyjnie określał działalność bieżącą, na którą się je przeznacza.

\subsection{Normatywne znaczenie definicji dotacji}

Definicja dotacji z art. 126 ufp oraz definicje trzech rodzajów dotacji nie mają charakteru naukowego, ale znaczenie normatywne. Definicje umożliwiają bowiem zaliczenie określonej płatności z budżetu - jako wydatku transferowego dokonywanego na podstawie przepisu prawnego - do dotacji jako takich. Zarazem definicje trzech rodzajów dotacji umożliwiają przyporządkowanie transferu, jeśli jest dotacją, do określonego rodzaju dotacji (celowej, podmiotowej bądź przedmiotowej). Następnie umożliwiają ustalenie (adekwatnie do rodzaju dotacji) szczegółowych elementów konkretnego tytułu dotacyjnego, czyli:

- kto jest beneficjentem,

- na co dotacja jest przeznaczona i do kiedy można nią dysponować,

- kto (jaki organ) jako donator jest właściwy do udzielania tego typu dotacji, 
- w jakim trybie dotacja jest przyznawana i wypłacana beneficjentowi,

- w jaki sposób, jakimi danymi i w jakim terminie beneficjent rozlicza się przed organem z wykorzystania dotacji.

Przykładem zastosowania norm definicji jest dotacja opisana ogólnikowo w art. 32 ust. 3 b ustawy $\mathrm{z}$ dnia 24 sierpnia 1991 r. o ochronie przeciwpożarowej (Dz.U. z 2009 r. Nr 178, poz. 1380 ze zm.). Według powołanego przepisu JST mogą przekazywać ochotniczym strażom pożarnym środki finansowe $\mathrm{w}$ formie dotacji. $\mathrm{Z}$ materiałów dokumentujących przebieg procesu uchwalenia noweli ww. ustawy wynika, że zamiarem ustawodawcy nie było odesłanie do już istniejących tytułów dotacyjnych w oparciu o które ochotniczej straży pożarnej można udzielić dotacji z art. 13-19a ustawy o działalności pożytku publicznego i o wolontariacie, art. 81 ustawy o ochronie zabytków i opieki nad zabytkami, czy dotacji z art. 403 ustawy z dnia 27 kwietnia 2001 r. Prawo ochrony środowiska (Dz.U. z 2013 r., poz. 1232 ze zm). Norma z art. 32 ust. 3 b wyraża samodzielny tytuł dotacyjny. Analizując przepis kolejno stwierdzamy, że dotacja przewidziana w przepisie nie spełnia cech dotacji przedmiotowej (brak wskazania stawek jednostkowych), ani cech dotacji podmiotowej (nie określenie dotowanej działalności bieżącej). W konsekwencji wnioskujemy, że przepis wyraża podstawę prawną do udzielania dotacji celowej. Uznanie, że mamy do czynienia $\mathrm{z}$ dotacją celową, a zarazem stwierdzenie niekompletności regulacji, powoduje zastosowanie dyspozycji $\mathrm{z}$ art. $250 \mathrm{ufp}, \mathrm{w}$ efekcie czego to $\mathrm{w}$ umowie doprecyzuje się przeznaczenie dotacji celowej, termin i sposób jej przekazania, sposób i termin rozliczenia oraz termin zwrotu niewykorzystanych środków do budżetu JST.

W analogiczny sposób przepisy-definicje znajdują zastosowanie do interpretacji wyrażających dotacje oświatowe przepisów art. 80 i 90 ustawy o systemie oświaty. Przepisy nie określają wprost rodzaju tych dotacji. Niemniej dotacje oświatowe dla szkół, przedszkoli lub placówek są dotacjami podmiotowymi $\mathrm{w}$ rozumieniu art. $131 \mathrm{ufp}$, ponieważ przepisy określają ich beneficjenta i działalność bieżącą na którą dotacja jest przeznaczona.

Należy podkreślić w tym miejscu, że brak norm-definicji powodowałby, że każda przewidziana w przepisach szczególnych dotacja byłaby samodzielnym rodzajem dotacji, co zobowiązywałoby ustawodawcę do zawierania w tytule prawnym znacznie obszerniejszej regulacji niż w dotychczasowych przepisach. Innymi słowy, byłoby tyle liczonych już na setki rodzajów dotacji, ile w prawie zawarto tytułów dotacyjnych. Tymczasem prawo przewiduje tylko trzy rodzaje dotacji. 


\section{Przepisy wspólne dotacjom}

Grupę norm prawa dotacyjnego nazwaną „przepisami wspólnymi” stanowią te przepisy ufp i przepisów odrębnych, które znajdują zastosowanie $\mathrm{w}$ fazie planowania oraz udzielania i rozliczania dotacji, jak również przepisy, które mogą znaleźć niekiedy zastosowanie, jeśli dotacja podlega zwrotowi lub gdy doszło do naruszenia norm prawa dotacyjnego (odpowiedzialność dyscyplinarna, odpowiedzialność karna skarbowa). Zamieszczenie tych przepisów w systemie prawnym powoduje, że kwestii w nich normowanych ustawodawca nie musi za każdym razem dodatkowo regulować w przepisach wyrażających tytuły dotacyjne ${ }^{11}$. Poniżej odniosę się do niektórych tylko przepisów $\mathrm{z}$ tej grupy norm prawa dotacyjnego.

\subsection{Wykonawcy budżetu JST w zakresie wydatków dotacyjnych}

Każda dotacja, aby jej udzielić, musi wywodzić się z odpowiedniego limitu na wydatki dotacyjne zamieszczonego w budżecie JST. Budżet nie jest jeszcze pełnym upoważnieniem do posługiwania się dotacjami. Zaplanowane w nim dochody i wydatki, celem ich wykonania, przenoszone są następnie do planów finansowych jednostek budżetowych danego samorządu (art. 249 ufp). Tam dokonuje się właściwe pozyskiwanie dochodów oraz związane $\mathrm{z}$ wydatkami zaciąganie zobowiązań ( $\mathrm{w}$ tym zawieranie umów o dotację) i wypłaty dotacji.

Według art. 249 ust. 4 ufp wyłącznie w planie finansowym urzędu JST (w tym starostwa) należy ujmować wszystkie dotacje zaplanowane w wydatkach budżetu. Jedynym odstępstwem jest możliwość zamieszczenia dotacji związanych z realizacją programów operacyjnych w planach jednostek budżetowych samorządu województwa (innych niż urząd marszałkowski). Przepis art. 249 ust. 4 ufp powoduje, że o ile prawnie możliwe jest zawieranie umowy o dotację przez inne niż urząd jednostki budżetowe, o tyle zawsze w gestii wójta (burmistrza, prezydenta miasta) oraz starosty i marszałka (albo upoważnionego pracownika urzędu $\mathrm{z}$ art. 53 ufp) pozostanie zarówno wypłata, jak i rozliczenie wszystkich dotacji z budżetu JST, w tym dotacji na zadania z zakresu pomocy społecznej,

11 Co do zasady, o zwrocie dotacji do budżetu JST stanowią przepisy art. 251 i art. 252 ufp. Poza czterema tam przewidzianymi sytuacjami, gdy ustawodawca nakłada obowiązek zwrotu dotacji, w przepisie art. 253 ufp zawarto odesłanie, w świetle którego w przepisach ustaw szczególnych mogą zostać zawarte inne jeszcze dodatkowe przesłanki powodujące powstanie obowiązku zwrotu dotacji do budżetu JST - odrębne w stosunku do sytuacji opisanych w art. 251 i 252 ufp. 
dotacji na wspieranie zatrudnienia oraz dotacji z ustawy o systemie oświaty. Jednostki specjalistyczne obsługi oświaty, instytucje pomocy społecznej czy administracja zatrudnienia nie mogą zajmować się udzielaniem i rozliczaniem dotacji, co zmusza pracowników urzędów JST do dypsonowania specjalistyczną wiedzą na temat ustaw, których nie realizuje urząd, a wcześniej wymienione jednostki specjalistyczne.

\subsection{Rozliczanie dotacji - jako czynności beneficjenta i donatora}

Zgodnie z definicją zawartą $\mathrm{w}$ art. 126 ufp od innych wydatków budżetowych dotacje odróżniają się szczególnymi zasadami ich rozliczania. Rozliczanie to zarówno czynność beneficjenta, jak i czynności kontrolne i decyzyjne organu (donatora).

Choć jest to cecha wspólna dotacjom, to w przepisach prawa finansowego brak jest regulacji ogólnej (wspólnej) normującej zasady rozliczania dotacji przez beneficjenta, których punktem odniesienia byłyby wszystkie rodzaje dotacji budżetowych.

Czynności beneficjenta w zakresie rozliczania dotacji wyrażone zostają $\mathrm{w}$ przepisach ustaw stanowiących podstawy prawne udzielania poszczególnych dotacji, w przepisach aktów wykonawczych do tych ustaw albo w umowach o dotację. Jako szczególne dla systemu prawnego uznać należy wcześniej wskazane rozwiązania z przepisów art. 150 i art. 160 ufp, według których w przypadku niezamieszczenia w przepisach szczególnych treści dotyczących rozliczania dotacji celowych przepisy ufp nakazują zawieranie umów uściślających wymienione kwestie podstawowe.

Typowe rozliczenie w organie dotacji wypłaconej ma na celu skontrolowanie i ustalenie:

- czy beneficjent był uprawniony do otrzymania dotacji?

- czy dotacja została wykorzystana zgodnie z jej przeznaczeniem? oraz

- czy wysokość wypłaconej kwoty dotacji była prawidłowa?

- czy i w jakiej kwocie organ powinien dopłacić beneficjentowi albo beneficjent zwrócić środki organowi?

Oprócz czynności beneficjenta, rozliczanie dotacji stanowi również o grupie obowiązków organu, który jej udzielił. Niezatwierdzenie rozliczania dotacji przez organ traktowane jest jako naruszenie dyscypliny finansów publicznych $\mathrm{z}$ art. 8 pkt 2 ustawy z dnia 17 lipca 2004 r. o odpowiedzialności za naruszenie dyscypliny finansów publicznych (Dz.U. z 2013 r., poz. 168). Przepis art. 8 pkt 3 powołanej ustawy jako naruszenie dyscypliny finansów publicznych traktuje również nieustalenie kwoty dotacji podlegającej zwrotowi do budżetu. 
Czynności rozliczeniowe po stronie organu obejmują sprawdzenie i weryfikację dokumentów rozliczeniowych przedstawionych przez beneficjenta oraz dalsze czynności wewnętrzne w jednostce budżetowej obsługującej udzieloną dotację. Po czynnościach sprawdzających musi zapaść rozstrzygnięcie w postaci akceptacji (zatwierdzenia) przedstawionego rozliczenia dotacji. Skoro jest to czynność z zakresu gospodarki finansowej, właściwy do jej dokonania jest kierownik jednostki budżetowej (z art. 53 ust. 1 ufp) lub pracownik upoważniony na zasadach i w formie określonej w art. 53 ust. 2 ufp. Dokumenty organu dotyczące zatwierdzenia rozliczenia dotacji, przed rozliczeniem dotacji, powinny być odpowiednio asygnowane przez głównego księgowego jednostki budżetowej na podstawie art. 54 ust. 1 i 3 ufp, gdyż bez tego decyzja o rozliczeniu nie podlega finansowemu (wewnętrznemu) wykonaniu. Rozliczenie dotacji, po uzyskaniu postaci „dowodu księgowego”, kierowane jest na stanowisko pracy obsługujące księgi finansowe jednostki budżetowej, gdzie obok związanych z dotacją zapisów o wydatku, zapisywany jest fakt jej rozliczenia. Odnotowane rozliczenie dotacji umożliwia zamknięcie księgowe roku budżetowego - „na zero”, albo z przypisem należności do zwrotu do budżetu, albo ze zobowiązaniem wyrównania dotacji wypłaconej do kwoty należnej (dopłata do dotacji często występuje w praktyce dotacji udzielanych corocznie prywatnym przedszkolom $\mathrm{z}$ art. 80 ust. 2 i 90 ust. 2b ustawy o systemie oświaty).

\subsection{Zwrot dotacji do budżetu (windykacja obowiązku)}

Prawo dotacyjne swoją regulacją obejmuje również kwestie związane z obowiązkiem zwrotu dotacji. Zwrot dotacji dokonuje się bądź to w fazie rozliczania dotacji, bądź nawet po pozytywnym jej rozliczeniu (bez zwrotu), gdy organ w wyniku późniejszych czynności kontrolnych poweźmie wiadomość, że dotacja lub jej część podlega zwrotowi.

Zagadnienia prawne zwrotu dotacji w ufp obejmują określenie:

1) przesłanek powodujących powstanie obowiązku zwrotu dotacji do organu,

2) sposobów obliczania odsetek (jak od zaległości podatkowych) z tytułu zwrotu dotacji,

3) kwestię dochodzenia przez organ wykonania ww. świadczeń pieniężnych (windykacja obowiązku zwrotu dotacji).

Regulację samego obowiązku zwrotu dotacji do budżetu zawarto odpowiednio w art. 168 i 169 ufp (dotacje z budżetu państwa) oraz w art. 251 i 252 ufp (dotacje z budżetu JST). Powołane przepisy określają również zasady naliczania odsetek od zwracanej kwoty - jak od zaległości podatkowych. Okolicznościami powodującymi powstanie po stronie 
beneficjenta obowiązku zwrotu dotacji, a po stronie organu - obowiązek dochodzenia zwrotu dotacji - są:

- niewykorzystanie (w całości lub w części) dotacji,

- otrzymanie dotacji nienależnej w całości,

- otrzymanie dotacji w części w wysokości wyższej niż wynikająca z prawidłowego obliczenia,

- wykorzystanie dotacji niezgodnie z przeznaczeniem.

Jak wynika $\mathrm{z}$ art. 253 ufp, cztery sytuacje powodujących zwrot dotacji, w przypadku dotacji z budżetu samorządu, mogą zostać uzupełnione o inne jeszcze przesłanki dla powstania obowiązku zwrotu dotacji, jakie wynikać mogą z przepisów szczególnych. Jak na razie ustawodawca w przepisach szczególnych nie przewidział dodatkowych jeszcze okoliczności dla zwrotu dotacji do budżetu JST, odrębnych od zasad z art. 251 i 252 ufp.

Przepis art. 169 ust. 6 ufp, odnoszący się do dotacji z budżetu państwa, zawiera podstawę prawną do wydania decyzji administracyjnej ustalającej kwotę, którą beneficjent ma zwrócić do budżetu państwa, oraz datę, od której naliczane są odsetki. Decyzja o zwrocie, po jej uprawomocnieniu, stanowi tytuł wykonawczy umożliwiający uruchomienie wobec beneficjenta egzekucji administracyjnej.

Niestety w zakresie dotacji z budżetu samorządu nie zawarto analogicznej podstawy prawnej do wydania decyzji windykacyjnej. Podstawa prawna wyprowadzana jest posiłkowo z przepisu art. $61 \mathrm{ufp}$, jednak jego treść literalna świadczy, że ustawodawca zawarł w nim jedynie normę o właściwości organów do wydawania decyzji, nie zaś normę kompetencyjną określającą treść decyzji windykacyjnej, jak z art. 169 ust. 6 ufp. Niewątpliwie art. 61 reguluje właściwość organów rządowych i samorządowych w sprawach załatwianych decyzjami administracyjnymi, których materię określa ustawa - czyli: decyzją o umorzeniu obowiązku zwrotu dotacji (art. 64 ufp) i decyzją o pobraniu zwrotu dotacji w drodze potrącenia z należności JST na rzecz zobowiązanego (art. 63 ufp). Innych „spraw administracyjnych” niż kwestie decyzji w zakresie ulg i potrąceń nie sposób z niego wyprowadzać.

\subsection{Udzielanie ulg w zakresie zobowiązań z tytułu zwrotu dotacji}

Jeśli kwota dotacji do zwrotu stanowi należność budżetu, to zobowiązanie beneficjenta do zwrotu dotacji podlega dochodzeniu ze strony organu, gdyż niedochodzenie tego rodzaju należności budżetowej sankcjonowane jest odpowiedzialnością z art. 5 ust. 1 pkt 2 ustawy o odpowiedzialności za naruszenie dyscypliny finansów publicznych. Wśród właściwych należnościom z tytułu dotacji przepisów art. 60 pkt 1- art. 67 ufp zawarto również regulację umożliwiającą udzielanie ulgi w spłacie 
tego rodzaju zobowiązania. Według art. 64 ufp na wniosek beneficjenta organ ( $\mathrm{z}$ art. $61 \mathrm{ufp}$ ) może udzielić ulgi rodzajowo określonej, jak ulga $\mathrm{z}$ art. 55 ufp - powodującej umorzenie zobowiązania, rozłożenie na raty, bądź przesunięcie terminu zapłaty. Ulga zamyka lub zawiesza dochodzenie zobowiązania od beneficjenta stanowiącego dochód budżetu państwa lub budżetu JST.

\section{Podsumowanie}

Przedstawiona struktura prawa dotacyjnego nie została zapisania w wyraźnych przepisach ją ustalających. Jej istnienia de lege lata można natomiast dowieść $\mathrm{w}$ wyniku analizy ustawodawstwa $\mathrm{z}$ tam występującym porządkiem trzech rodzajów przepisów prawa o dotacjach. Opisana struktura umożliwia ustalenie zasad ogólnych prawa dotacyjnego, jakie ułatwiają interpretację aktualnych przepisów dotyczących dotacji oraz umożliwiają prawidłowe budowanie nowych przepisów - tytułów dotacyjnych. Wnioski z analizy prawa dotacyjnego dowodzą występowania w nim również braków i nieścisłości, tak w przypadku niektórych tytułów dotacyjnych, jak i braków w przepisach wspólnych. Naocznym tego przykładem jest niezamieszczenie w ustawie o finansach publicznych wyraźnej podstawy prawnej do wydawania decyzji administracyjnej o zwrocie dotacji do budżetu samorządu.

$\mathrm{Na}$ tle reform prawa samorządowego i reform prawa finansowego należałoby ponawiać postulaty podnoszone przy okazji wcześniejszych nowelizacji trzech kolejnych ustaw o finansach publicznych, aby w ustawie w sposób wyraźny zapisać strukturę prawa dotacyjnego. Właściwe zgrupowanie i uzupełnienie w jednej ustawie norm ogólnych i wspólnych dotacjom będzie dyscyplinować autorów nowych ustaw szczególnych, aby de lege ferenda wyrażali kompletne tytuły dotacyjne. Powinno to również spowodować poprawienie i uzupełnienie niekompletnych tytułów dotacyjnych w obowiązującym ustawodawstwie i aktach wykonawczych. 


\section{Bibliografia}

Borodo A., Samorząd terytorialny. System prawnofinansowy, Warszawa 1997.

Chojna-Duch E., Struktura dotacji budżetowej. Studium teoretycznoprawne, Warszawa 1988.

Dębowska-Romanowska T., Zagadnienia prawne wydatków na rzecz osób trzecich, Łódź 1993.
Malinowska-Misiąg E., Misiąg W., Finanse publiczne w Polsce, Warszawa 2007. Owsiak S., Finanse Publiczne. Teoria i praktyka, Warszawa 1997.

Wyrok Naczelnego Sądu Administracyjnego z dnia 12 grudnia 2013 r. (II GSK 1482/12). 